\begin{tabular}{|c|c|c|}
\hline President: & Prof. D. W. ROBINSON & $\begin{array}{l}\text { Department of Mathematics } \\
\text { Australian National University } \\
\text { ACT } 0200\end{array}$ \\
\hline Secretary: & Prof. D. ElLloTt & $\begin{array}{l}\text { Department of Mathematics } \\
\text { The University of Tasmania } \\
\text { G.P.O. Box } 252 \text { C } \\
\text { Hobart Tasmania } 7001\end{array}$ \\
\hline Treasurer: & Dr A. HowE & $\begin{array}{l}\text { Mathematics Department } \\
\text { Australian National University } \\
\text { Canberra ACT } 0200\end{array}$ \\
\hline $\begin{array}{l}\text { Membership subscriptions } \\
\text { (for 1995) }\end{array}$ & $\begin{array}{l}\text { Institutions: } \\
\text { Ordinary members: } \\
\text { Reciprocal members: } \\
\text { Reduced rate members: } \\
\text { Sustaining members: }\end{array}$ & $\begin{array}{l}\text { A } \$ 762 \text { (this includes all publications) } \\
\text { A\$65 (A\$60 if paid before } 31 \text { Dec.95) } \\
\text { A\$33 } \\
\text { A\$12 } \\
\text { A } \$ 130\end{array}$ \\
\hline
\end{tabular}

Reciprocity agreements: Such agreements have been made with a number of other mathematical societies. Under the agreements. members of the other societies who are not normally resident in Australia may join the Australian Mathematical Society at the rate shown.

Membership and correspondence: Applications for membership, subscriptions, changes of address or title or position, correspondence about accounts or distribution of the Society's journals, and orders for back numbers should be sent to the Treasurer. All other correspondence should be sent to the Secretary.

Members receive the Gazette free and are entitled to purchase other publications at the following annual rates (1995): Journal (Series A) A\$33, Journal (Series B) A\$25, Bulletin A\$30. For reduced rate members, the subscription prices are half those quoted.

\title{
OTHER PUBLICATIONS OF THE SOCIETY
}

JOURNAL of the Autralian Mathematical Society, Series A (Pure Mathematics and Statistics).

Six parts will be published in 1995, cost A\$273 per year.

Editor: Dr J. GROVES, Department of Mathematics, University of Melbourne, Parkville, Vic. 3052 .

BULLETIN of the Australian Mathematical Society aims at quick publication of original research in all branches of mathematics. Six parts will be published in 1995. cost A\$250 per year.

Editor: Dr A. S. JONES. University of Queensland, Qld 4072.

GAZETTE carries news items, mathematical articles of general interest, and articles on tertiary mathematics teaching. The 1995 cost is A\$48 per year.

Editor: Prof. T. M. MiLLS, Department of Mathematics. La Trobe University, Bendigo, Vic. 3550 .

\section{Copyright Statement}

Where necessary, permission to photocopy for internal or personal use of specific clients is granted by the Treasurer. Australian Mathematical Publishing Association, Inc., to libraries and other users registered with the Copyright Clearance Center (CCC). provided that the base fee of A\$2.00 per copy of article is paid directly to CCC, 27 Congress St, Salem, MA 01970, U.S.A. Special requests should be addressed to the Treasurer, Australian Mathematical Publishing Association. Inc.. Mathematics Department, Australian National University, Canberra, ACT 0200, Australia. Serial-fec code: 0334-2700/95.

(C) Copyright Australian Mathematical Society 1995 


\section{PREPARATION OF MANUSCRIPTS}

Authors of articles submitted for publication in the Journal are asked to ensure that their manuscripts are in a form suitable for sending to the printer. The Editor reserves the right to retum poorly presented material to authors for revision.

1. Submission. This journal is typeset in LaTeX. It will speed up processing of accepted papers if an electronic version of the manuscript, preferably TeX-based, is available. However, such a file need not be sent with the submitted paper, but will be requested by the Editor if the paper is accepted. The author should submit three copies to the Editor or an appropriate Associate Editor.

2. Abstract. An abstract not exceeding 250 words should be included in the manuscript.

3. Style. The manuscript should conform to the following rules. In case of any doubt, authors are advised to refer to previous papers in the Journal.

Main headings should be numbered, centred and shown thus:

\section{Preliminary results}

The titles Lemma, Theorem, Proof, Corollary, Remark, Definition etc, should be leftjustified and numbered consecutively with arabic numerals, e.g.

LEMMA I. The content of the lemma, theorem etc. should follow, as here.

Manuscripts should be typed, on high quality A4 or quarto bond paper, one side only with at least double spacing, and with a margin of at least $4 \mathrm{~cm}$ all around. If the title is long, supply also a shortened form of the title not exceeding $\mathbf{4 0}$ characters, including spaces. If acknowledgements of support and assistance are made, these should be given at the end of the article. Footnotes should be avoided. The address should be shown under the author's name.

4. Equations. Equations should be typed wherever possible, and punctuated to conform to their place in the syntax of the sentence. Equation numbers should be shown on the right in round brackets.

5. References. The reference list should be in ALPHABETICAL ORDER by name of first author, preceded by a reference number in square brackets. These references should be cited in the text by giving the appropriate number in square brackets. The following layout for books, journal articles, technical reports, theses, articles in books, and conference proceedings respectively, must be followed.

[1] M. Abramowitz and I. A. Stegun (eds.), Handhook of mathematical functions (Dover, New York, 1970).

[2] S. N. Biswas and T. S. Santhanam, "Coherent states of para-Bose oscillators", J. Austral. Math. Soc. Ser. B 22 (1980) 210-217.

[3] F. H. Busse, "On the mean field problem of thermal convection", Max-Planck Inst, Phys. Astrophys. Rep. MPI-PAE/Astro 31 (1970) 1-31.

[4] E. M. Casling, "Slender planing surfaces", Ph. D. Thesis, University of Adelaide, 1978.

[5] R. H. Day. "Adaptive processes and economic theory", in Adaptive economic models (eds. R. H. Day and T. Groves), (Academic Press, New York, 1975) 1-38.

[6] J. W. Miles, "Resonant response of harbors (the harbor paradox revisited)", Proc. 8th Symp. Naval Hydro. (1970) 95-115.

6. Tables. Each should be typed on a separate sheet with a centred heading TABLE 1 (or 2,3, etc.), followed by a caption. The location should be shown in the text, e.g.

TABLE 1 NEAR HERE

7. Figures. Each figure should have a caption beginning: FIGURE 1 (or 2, 3, etc.). A list of these captions should be provided on a separate page at the end of the manuscript. Location of figures in the text should be shown, e.g.

\section{FIGURE 1 NEAR HERE}

Figures should be drawn in black ink with clean lines; do not use a ball point pen. The paper should be of a non-absorbent quality so that the ink does not spread and produce fuzzy lines. If the figures are intended for reduction they should be drawn with lines heavy enough that they do not become flimsy at the desired reduction. The lettering should be of professional quality and in proportion for the expected size reduction. That made with dry transfer lettering, lettering guide or scriber is most appropriate. If none of these possibilities is available, write in the lettering with pen or pencil, not obliterating any lines of the drawing; the lettering will then be typeset.

8. Units. The SI system of units should be used. 